FACTA UNIVERSITATIS

Series: Law and Politics Vol. 16, N ${ }^{\circ}$ 2, 2018, pp. 91-100

https://doi.org/10.22190/FULP1802091G

Original Scientific Paper

\title{
GOALS OF THE NATIONAL BANK OF SERBIA*
}

UDC 336.711(497.11)

\section{Srdjan Golubović, Nataša Golubović}

Faculty of Law, University of Niš, Serbia

Faculty of Economics, University of Niš, Serbia

\begin{abstract}
Starting from the legal position of the National Bank of Serbia, the paper analyzes the objectives entrusted to this institution by domestic legislation. In line with the dominant monetary paradigm, the main goal of the central bank of Serbia is price stability. After the global financial crisis, financial stability is increasingly mentioned as the objective that central banks implement. This also applies to the central bank in Serbia (National Bank of Serbia), which has a clear mandate to take account of financial stability, in addition to monetary stability. Finally, as an important subject of economic policy, the National Bank of Serbia, by exercising the entrusted functions also affects the achievement of other economic policy objectives. It should be kept in mind that domestic legislation precisely determines the hierarchy of the objectives of the central bank, considering that it explicitly stipulates that the National Bank of Serbia primarily takes care of monetary and financial stability, and only then it provide support for general economic policy, provided that it does not jeopardize the exercise of the basic objectives.
\end{abstract}

Key words: National Bank of Serbia, objectives, monetary and financial stability, economic policy.

\section{INTRODUCTION}

The Central Bank is a public institution that plays a major role in organizing, directing and regulating monetary flows. In contemporary legislation, central banks enjoy a high degree of independence and autonomy in exercising entrusted tasks and functions. In line with the dominant monetary paradigm, this legal status protects the central bank from political influence and allows it to achieve established goals and tasks. With the adoption

Received September $24^{\text {th }}, 2018$ / Accepted October $31^{\text {st }}, 2018$

Corresponding author: Prof. Srdjan Golubović, LL.D., Full Professor, Faculty of Law, University of Niš, Trg kralja Aleksandra 11, 18000 Niš, Republic of Serbia

E-mail: golub@prafak.ni.ac.rs

* Prepared within the project Sustainability of the Identity of Serbs and Ethnic Minorities in Border Municipalities in Eastern and Southern Serbia (179013), which is carried out by the Faculty of Mechanical Engineering, University of Niš, and funded by the Ministry of Science and Technology of the Republic of Serbia. 
of the Constitution in 2006, Serbia joined the group of countries that further strengthen the position of the monetary authority in relation to the executive power. However, mere introduction of a provision on the central bank independence in the highest legal act of the country is not enough. Other elements included in the law, which constitute the content of institutional, functional (operational), financial and personal independence, are also relevant for assessing the degree of independence of this institution. The position of the central bank vis-à-vis the executive power also depends on how the objectives, whose realization is the responsibility of the central bank, are defined. Until the outbreak of the global financial crisis in 2007 , central banks primarily took care of price stability. In response to the crisis, central banks are reverting to a traditional role, which implies that central banks are increasingly taking into account financial stability. In this paper, after analyzing the legal status of the National Bank of Serbia, the authors consider its role in establishing and preserving monetary and financial stability. In the last part of the paper, obligation of the National Bank to support the realization of other economic policy objectives by performing its functions is investigated.

\section{The Legal Articulation of the NATIONAL BANK OF SERBia Status}

The inclusion of Serbia in the European integration process imposes the need to harmonize domestic legislation with the EU law. An integral part of this process is the implementation of EU standards for the central bank as an independent institution which, protected from the influence of political entities, conducts monetary policy in order to maintain price stability as a priority goal. The status, goals, tasks and organization of the central bank are regulated in detail by the Act on the National Bank of Serbia (hereinafter: NBS Act) of 2003, which has been amended several times to this day. ${ }^{1}$ With the adoption of the Constitution in 2006, Serbia joined the group of countries that further strengthen the position of monetary authorities in relation to other forms of government by introducing a provision on the central bank independence in the highest legal act of the country. ${ }^{2}$ According to positive regulations, the National Bank of Serbia (NBS) is autonomous and independent in conceiving and managing monetary and foreign exchange policy and performing other functions determined by the law. However, provisions that form the essence of institutional, functional (operational), financial and personal independence are much more relevant for assessing the legal status of the central bank. In this respect, the degree of institutional independence of the central bank is assessed on the basis of provisions defining the position of the National Bank of Serbia in relation to other forms of the government. Article 2 of the NSB Act stipulates that NBS and its bodies (including members of those bodies) "do not receive or seek instructions from state bodies and organizations, as well as from other persons, in the performance of their functions". In addition, the same article emphasizes the obligation of state authorities, organizations and other persons not to jeopardize the autonomy and independence of the central bank by their actions, i.e. they must not influence the central bank, its bodies or members of those bodies. Functional independence refers to the independence of the central bank in the performance of

\footnotetext{
${ }^{1}$ Act on the National Bank of Serbia, Official Gazette RS, 72/2003 and Act on Amendments to the Act on the National Bank of Serbia, Official Gazette RS, 55/2004, 85/2005 - dr. 44/2010, 76/2012, 106/2012 i 14/2015.

${ }^{2}$ According to Article 95 of the Serbian Constitution, "the NBS is autonomous and subjected to parliamentary supervision, to which it is accountable"; Constitution of the Republic of Serbia, Official Gazette RS, 98/06.
} 
entrusted functions. In addition to conducting monetary and foreign exchange policy, according to Article 4 of the NBS Act, the central bank performs the issuing function, ensures smooth functioning of payment operations in the country and abroad, and conducts the process of restructuring of banks or members of the banking group. In exercising these functions, the National Bank of Serbia completely independently makes decisions upon the application of instruments and measures envisaged by the law. However, this independence does not include freedom in determining the objectives whose implementation is the responsibility of the central bank, nor is it left to the discretion of the central bank to decide which goal will have a priority. Instead, the law defines the objectives which the central bank is responsible to accomplish. As with other central banks, domestic legislation requires the central bank to be primarily concerned with price stability. In addition, the NBS is also obliged to take into account financial stability or implementation of other economic policy objectives, provided that this does not jeopardize the achievement of a priority objective.

Considering the bank financing method, decisions upon the use of its own funds, distribution of profits, or coverage of eventual losses (according to Article 78 of the NBS Act, if there are insufficient assets of the central bank, then budget funds or securities issued by the Republic of Serbia are used), the National Bank of Serbia enjoys a high degree of financial independence. A key indicator for assessing the degree of central bank independence is the introduction of legislative provision that prohibits financing of the budget deficit through the central bank lending (Lastra, 2006: 49). Article 62 of the NBS Act contains this prohibition which, in accordance with EU standards, implies the prohibition of granting loans, borrowings, overdrafts and other forms of credit facilities to the state, autonomous province or local self-government units, as well as to legal entities where the aforesaid subjects are founders or have majority control. The prohibition of fiscal financing also refers to the provision of guarantees or otherwise ensuring the settlement of obligations of the aforesaid legal entities. The financing of the fiscal deficit by monetary expansion is further limited by the prohibition of the purchase of securities issued by those entities at the primary financial market.

In addition to the aforementioned indicators, the degree of central bank independence depends on the manner in which management of the central bank is regulated (the role, status and structure of central bank bodies, the procedure of selection and duration of the governor's mandate, incompatibility clause, etc.). According to Article 12 of the NBS Act, NBS bodies are the Executive Board, the Governor and the Council. The Executive Board, consisting of the Governor, the Director of the Supervision Department (operating within the NBS) and the Vice Governors, is responsible for conceiving monetary and foreign exchange policy. The members of this body are elected by the National Assembly for a period of six years, whereby the Governor is elected at the proposal of the President of the Republic of Serbia, the Director of the Supervisory Board is elected at the proposal of the National Assembly Committee in charge of finance, and Vice Governors are elected at the proposal of the Governor of the NBS.

The introduction of these elements into the legislative framework enables the National Bank of Serbia, as an independent institution, to freely make decisions about the monetary policy program and the instruments for its implementation. The NBS enjoys this freedom even when performing other functions entrusted by the law. Such legal position protects the National Bank from political influence, i.e. the abuse of monetary policy in order to gain political benefits. 


\section{MONETARY AND FINANCIAL STABILITY}

The central bank independence implies freedom in conceiving and implementing monetary policy programs, but it does not include freedom of choice in setting the goals. According to the prevailing paradigm at the beginning of the 1990s, monetary policy should have only one goal - price stability. Almost universal acceptance of this paradigm has triggered a wave of changes in the central bank legislation in order to emphasize price stability as the main goal to be attained by an independent central bank institution (Lastra, 2015: 58). Our legislation also does not envisage the disretion of the central bank in the choice of objectives, but explicitly determines the goals it will pursue. Thus, Article 3 of the NBS Act stipulates that the main goal of the central bank is "to achieve and maintaine price stability". The law, however, does not specify which inflation rate is acceptable, nor does it envisage the inflation rate by which monetary stability is considered to have been achieved. In an effort to define the legal framework for monetary policy implementation, the National Bank of Serbia made an agreement with the Government, which envisages that the stability-oriented monetary policy strategy will be implemented by using the target inflation rate regime. ${ }^{3}$ The target inflation rate implies determining the inflation corridor within which the inflation rate can move, without disturbing price stability. What needs to be kept in mind is that, in this way, targeted inflation is defined as a medium-term objective, meaning that in the short run, depending on the market trends, deviations from the defined goal are possible. By anouncing the value of target inflation, the frameworks for deciding on monetary policy in the medium term are defined and, at the same time, they anchor and stabilize the inflationary expectations of economic actors.

The financial crisis in 2007 and the consequent recession showed that the stability of the financial system as a whole is extremely important for monetary stability. Financial institutions take up numerous risks in their operations. Banks, insurance companies, investment funds and other financial intermediaries entering into financial transactions face credit risk, liquidity risk, interest rate risk, but also other types of risks (operational and business risks). In the market economy, financial institutions which are exposed to excessive risk are prone to decline. Although a vital financial system can isolate negative effects of the collapse of certain financial institutions, the state does not stand aside but strives to enhance risk management and prevent the emergence of the so-called domino effect by developing appropriate regulatory framework. In their operations, financial institutions are obliged to comply with regulatory standards on capital adequacy, limitation of to exposure risk, allocation of reserves and classification of receivables. Compliance with these standards is ensured by the supervision of the operations of a particular financial institution (microprudential supervision), which can be entrusted to a central bank or a special regulatory body. There are two basic objectives of microprudential supervision: first, continuous improvement of the performance and structure of financial entities; and second, maintaining an adequate level of stability and trust in their operations. In this way, clients of financial institutions are protected from losses, given that the achievement of these objectives contributes to establishing an optimal relationship between maximizing profits (as the goal pursued by financial institutions in their operations) and preserving their liquidity and solvency (as objectives that the beneficiaries of financial services as

\footnotetext{
${ }^{3}$ the Agreement between the National Bank of Serbia and the Government of the Republic of Serbia on targeting inflation, dated 19 December 2008; www.nbs.rs
} 
well as the state are strongly interested in implementing). Regulatory standards, together with a clearly defined way of supervising banks, constitute a legal environment that should reduce the depositor risk and encourage competition in financial mediation (Božina, 2006: 109).

The financial crisis, which in the period 2007-2009 first affected the most developed countries and then expanded to other countries, showed that monitoring the stability and reliability of individual financial institutions is not enough. The basic reason for the limited scope of microprudential control should be sought in the changes of the modern financial system caused by deregulation, fast growth of the financial transactions and the emergence of complex financial instruments. In such conditions, the peril of systemic risk has been shown to be quite real, despite the effective risk management at the level of individual entities. Typically, systemic risk is defined as a disturbance caused by the fall of one or more systemically important financial institutions, which not only affects the financial system as a whole, but also negatively affects the functioning of the whole economy (Lastra, 2011: 200). Systemic risk jeopardizes the performance of key functions of the financial system: informative, allocative, but also the function of risk management and the transfer of financial assets. Failure or disruption in the performance of these functions entails high costs for both economic actors and the society as a whole. In addition to direct costs in the form of losses of the providers and beneficiaries of financial funds, or increased expenditures in the budget for the purpose of covering the losses of financial institutions, the crisis of the financial system also entails significant indirect costs. They are measured by lost confidence in the financial system institutions and, in connection with this, by reduced volume of deposits, higher costs of financial mediation and low competitiveness.

In order to maintain favorable macroeconomic performance, the central bank cannot stand aside by taking care only of monetary stability (Bernanke, 2013: 11). The global financial crisis has shown that, among all institutions, only the central bank has the necessary capacity to prevent the collapse of the financial system by using appropriate instruments. There are several reasons that justify the responsibility of the central bank for financial stability. First, the central bank is the only institution that is authorized to issue money as a legal means of payment and affect the level of direct liquidity. Secondly, the central bank is responsible for the smooth functioning of payment transactions. And finally, the central bank is, quite naturally, interested in sound financial institutions and a stable financial market, which facilitate the monetary policy transmission (Schinasi, 2006: 137).

In response to the global financial crisis, a range of goals whose implementation is the responsibility of the central bank is expanding because, in addition to the price stability as a priority goal, the responsibility of the central bank for financial stability is becoming more and more clearly established. The mandate of the NBS to conduct macroprudential policy is defined by the amendments to the Act on the National Bank of Serbia of 2010, which established the obligation of the NBS to undertake activities and measures within its competence in order to preserve and strengthen the stability of the financial system. With thus defined competence, the NBS joins a group of central banks whose responsibility for financial stability is almost equal to the responsibility for implementing the monetary policy. The accomplishment of this goal implies synchronized action of several different factors. The first line of defense includes the activities of banks and other financial institutions undertaken to minimize the risks they face in their operations. According to 
the Banks Act ${ }^{4}$, the bank is obliged to identify, measure and evaluate the risks to which it is exposed in its operations, and to manage those risks. Also, the bank is obliged to establish and implement an efficient internal control system in a manner that ensures continuous monitoring of the risks that the bank is exposed to or may be exposed to in its operations. The second line of defense is the exercise of a microprudential policy. In practice, different solutions can be distinguished, including the transfer of jurisdiction for this activity to special institutions and entrusting the function of supervision to the central bank. Our legislation envisages that the central bank is responsible for conducting control and supervision activities over banking and non-banking financial institutions. According to the NBS Act (Article 8a), Supervision Department was created within the National Bank of Serbia to supervise the operation of financial institutions. In performing this function, the Supervisory Board independently, or in cooperation with the Executive Board of NBS, performs numerous activities that can be systematized into three groups: a) prudential regulation (i.e. rules that financial institutions must apply in their operations in order to ensure efficient risk management and security of depositor funds; b) prudential supervision (efficient supervisory system, precise competence of the bodies involved in supervision, their operational independence, transparency, manner of controlling the prudence and legality of financial institutions' operations); c) application of corrective and coercive measures (the supervisory institution must have appropriate tools which will order the elimination of irregularities in operations, as well as the possibility of revoking the operating licenses for banks and non-banking institutions). Finally, the third level of defense of financial stability includes macroprudential policy. The NBS Act entrusts the central bank with the competence to conduct macroprudential policy. Under this Act, the National Bank of Serbia "determines and implements, within its competence, activities and measures in order to preserve and strengthen the stability of the financial system" (Article 4, point 4, NBS Act). It should be kept in mind is that the fulfilment of the goals related to financial stability implies full commitment not only on the part of the central bank but also on the part of other entities whose operations affects financial flows. In this respect, it is extremely important to create an appropriate institutional framework for cooperation and concerted action by all stakeholders. However, it seems that a better solution for the alignment of policies and measures and the timely and efficient exchange of information in this area is the adoption of a special law that would regulate all matters of importance for financial stability. The key questions that would be regulated by this law are related to the establishment of an interinstitutional body in charge of financial stability, defining and implementing of the macroprudential policy.

\section{SUPPORT TO OTHER ECONOMIC POLICY OBJECTIVES}

Monetary and financial stability are fundamental objectives of the central bank. But, also, there are goals that have a major impact on the success of other segments of economic policy. Therefore, a monetary policy conducted by a central bank cannot be viewed as being isolated from the government's economic policy. Taking into account this interdependence, modern monetary legislation seeks to norm not only the responsibility of the central bank for monetary and financial stability but also to envisage

\footnotetext{
${ }^{4}$ Article 28, Act on Banks, Official Gazette RS, 107/2005, 91/2010 and 14/2015.
} 
its obligation to support the attainment of other economic policy objectives. Thus, according to Article 127 of the Consolidated TEU and TFEU, "The primary objective of the European System of Central Banks (ESCB) is to maintain price stability"; but, "without prejudice to the objective of price stability, the ESCB will support general economic policies in the Community". 5 This support should contribute to achieving the the objectives which, according to Article 3 of the Treaty on European Union encompass sustainable and non-inflationary growth, respecting the environment and high levels of employment and social protection. In a similar way, the NBS Act (Article 3, para. 3) stipulates that the National Bank shall, without jeopardizing monetary and financial stability, support the economic policy of the Government. What is lacking in domestic legislation is the concretization of the economic policy objectives that the NBS supports with its policy. Instead, it is emphasized that support for general economic policy should be in line with the principles of a market economy. The analysis of the norm contained in the aforementioned article of the NBS Act shows that support to the implementation of the economic policy is of conditional nature because the NBS will pursue this goal only if it does not impair the established monetary and financial stability. Likewise, the content of the norm shows that the central bank's hierarchy of objectives is clearly defined, given that it primarily takes care about the stability of prices and the financial system and, only if the above-mentioned condition is fulfilled, supports the objectives of economic policy. The existence of the scale of the central bank priority goals precludes any doubt in the firm commitment of the central bank to preserve price stability. Separating monetary stability as a priority goal suppresses inflationary expectations, which can hinder or jeopardize economic growth and job creation. Therefore, in its operations, the central bank primarily takes into account the achievement of the basic goal, but its role does not end there; as an important subject of economic policy, it can influence the achievement of other economic policy objectives. Of course, this does not mean that the central bank assumes responsibility for the overall economic policy. The accomplishment of other economic policy objectives remains the responsibility of the Government, but this provision seeks to ensure that the central bank carries out delegated functions in coordination with the government, thus creating a favorable environment for economic growth and development.

The capacity of the National Bank of Serbia to influence the achievement of economic policy objectives is determined by the functions entrusted to the central bank by the NBS Art (Article 4); the most important functions for the economic-political role of the central bank are:

a) the function of regulating cash flows: By performing this function, the central bank seeks to ensure a sufficient level of liquidity that will, without compromising price stability, create favourable environment for economic activity. Closely related with this function is also the obligation of the National Bank to ensure smooth functioning of payment transactions in the country and abroad.

b) the function related to regulation of banks' credit activities: One of the key tasks of the central bank is the impact on the credit activities of banks. The Central Bank has powerful tools that influence the credit potential and credit policy of banks, and consequently the achievement of other economic policy goals. Through the open market operations, i.e. purchases and sales of securities by the central

\footnotetext{
${ }^{5}$ Consolidated versions of the Treaty on European Union and the Treaty on the Functioning of the European Union, Official Journal of the European Union, 2012/C 326/01.
} 
bank, but also by using other instruments, it affects behavior of financial institutions, thus supporting the economic policy of the government. To support the economic policy goals, especially in the conditions of crisis, the function of the "lender of the last resort" is extremely important; it allows this institution to take timely interventions (by granting loans to banks in conditions "when other banks are unable or unwilling to do so") and prevent collapse of the financial system, with all the negative consequences for economic growth and employment (Djukic, 2016: 13).

c) the control function of the National Bank of Serbia: The control function of the National Bank of Serbia refers to banks, insurance activities, financial leasing transactions and voluntary pension funds, payment transactions and the protection of the rights and interests of the beneficiaries of services provided by these institutions. The dominant role of the banking sector in the financial system, the strong linkage between the central bank and commercial banks and the appropriate staffing potential are the reasons for entrusting this function to the National Bank of Serbia. In addition, the NBS Act entrusts the National Bank of Serbia with the function of bank restructuring (Article 65a and Article 65b NBS Act); in addition to being important for the stability of the banking system, this function has a significant impact on the overall business environment and, consequently, the accomplishment of other goals of economic policy.

d) Regulatory role, i.e. the authority of the National Bank to adopt regulations and other general acts. The regulatory role corresponds to the specific position of the National Bank of Serbia which, as an independent institution, has the authority to adopt certain general acts. In carrying out its functions and policy management, the National Bank has the right to make decisions and take measures in relation to the implementation of these policies. Within this function, the NBS is authorized to provide recommendations and opinions on the legislation in the preparation and regulatory frameworks of the financial system. Yet, it should be kept in mind is that the regulatory power of the NBS is not unlimited, which means that it can be manifested only in the areas under its jurisdiction and directly for the purpose of performing the entrusted tasks.

The establishment of the National Bank's obligation to support the government's economic policy includes the existence of proper cooperation between the central bank and the Government. According to Article 10 of the Law, the NBS cooperates with the Government and other state bodies in the performance of its functions. This cooperation can take different modalities (the presence of the Minister of Finance in the meetings of the Executive Board, i.e. the presence of Governor in the Government sessions, giving opinions on draft laws related to the functions of the central bank, the budget memorandum, economic and fiscal policy, information on the debts of the Republic abroad) with the goal of avoiding the conflict between economic policy objectives when defining the economic policy program, or the phenomenon that the realization of one goal impedes the achievement of another goal. The effectiveness of the economic policy program depends on its consistency, or the consistency of objectives, instruments and measures that it envisages. What should be kept in mind is that this cooperation between the central bank and the government should in no case be the basis for the unallowed influence on the monetary authority, which, as already mentioned, enjoys full autonomy in the exercise of entrusted functions. 


\section{CONCLUSIONS}

The National Bank of Serbia is an independent public institution that has a very complex and responsible role. The analysis of domestic legislation shows that it enjoys institutional, functional (operational), financial and personal independence. This legal status gives the NBS full freedom in conceiving and implementing monetary policy programs and performing legally entrusted functions. Independent status, however, does not include the freedom to choose the goals that the central bank will implement. In accordance with the ruling monetary paradigm, the freedom of choice of goals is omitted from the concept of independence, since in this way one extremely important leverage of power could be removed from the control of other forms of power and left to the free will of the central banker. Therefore, as in most other countries, the law explicitly determines the goals of the National Bank of Serbia. According to domestic legislation, monetary stability is the main goal of the central bank. Until the outbreak of the financial crisis in 2007, the prevailing view was that the central bank should take into account only one objective - that of the price stability. After the crisis, central banks (and even the NBS) became increasingly aware of the need to reduce systemic risk, which jeopardizes the performance of the key functions of the financial system: informative, allocative, but also the function of risk management and transfer of financial assets, with negative effects on economic growth and employment rate. The fact that financial instability entails high costs, both for economic actors and for the society as a whole, is the reason why central banks are giving increasing importance to strengthening and preserving financial stability. In addition to monetary and financial stability, the National Bank of Serbia is obliged to support the realization of other economic policy objectives through its activities. However, supporting the implementation of economic policy is of a conditional nature, since the NBS is trying to achieve this goal only if it does not impair the established monetary and financial stability. These responsibilities are secondary, given that domestic legislation clearly determines the hierarchy of the central bank's objectives. With the seclusion of monetary stability (and after the global financial crisis - financial stability), as a priority goal of the central bank, any doubt about possible misuse of monetary policy is eliminated, which would not only impair stability, but also negatively affect economic growth.

\section{REFERENCES}

Bernanke, B. (2013). A Century of US Central Banking: Goals, Frameworks, Accountability, Journal of Economic Perspectives, Vol. 27., No. 4., 2013, pp. 3-16.

Božina, M. (2006). Pravni i ekonomski aspekti regulacije poslovnih banaka u procesu ekonomske i monetarne integracije Republike Hrvatske (Legal and Economic Aspects of Banking Regulations in the process of economic and moneteray integration of the Republic of Croatia), Ekonomska istraživanja, Vol.19, No. 2, 2006, pp.107-117

Đukić, Đ. (2017). Centralna banka i finansijski sistem (The Central Bank and the Financial System), Centar za izdavačku delatnost Ekonomski fakultet, Beograd.

Lastra, R., (2015). International Financial and Monetary Law, Oxford University Press, New York.

Lastra, R. (2011). Systemic Risk, SIFIs and Financial Stability, Capital Markets Law Journal, Vol. 6, No. 2, 2011, pp.197-213

Lastra, R. (2006). Legal Foundations of International Monetary Stability, Oxford University Press, New York

Schinasi, G. J.(2006). Safeguarding Financial Stability: Theory and Practice, Washington, D.C.: International Monetary Fund 


\section{CILJEVI NARODNE BANKE SRBIJE}

U radu se polazeći od pravnog položaja Narodne banke Srbije analiziraju ciljevi koje domaće zakonodavstvo poverava ovoj instituciji. U skladu sa dominantnom monetarnom paradigmom, osnovni cilj centralne banke Srbije je stabilnost cena. Nakon globalne finansijske krize, u domenu ciljeva, koje centralne banke realizuju, dolazi do promene u smislu da se kao cilj sve češće pominje finansijska stabilnost. To važi i za centralnu banku Srbije koja ima jasan mandat da, pored monetarne stabilnosti, vodi računa i o finansijskoj stabilnosti. Najzad, kao bitan subjekt ekonomske politike, Narodna banka Srbije obavljanjem poverenih funkcija utiče $i$ na ostvarivanje ostalih ciljeva ekonomske politike. Ono što treba imati u vidu to je da domaće zakonodavstvo precizno određuje hijerarhiju ciljeva centralne banke, budući da se izričito propisuje da Narodna banka Srbije prvenstveno brine o monetarnoj i finansijskoj stabilnosti, pa tek onda, i pod uslovom da se time ne ugrožava realizacija osnovnih ciljeva, i o podršci opštoj eknomskoj politici.

Ključne reči: Narodna banka Srbije, ciljevi, monetarna i finansijska stabilnost, ekonomska politika.

Proofreading:

Gordana Ignjatović 